\title{
PEMANFAATAN SITUS SEJARAH CANDI JABUNG SEBAGAI SUMBER BELAJAR UNTUK MENINGKATKAN BERPIKIR KRITIS MAHASISWA IPS
}

\author{
Siti Nurul Hidayah \\ Institut Ilmu Keislaman Zainul Hasan (INZAH) Genggong Probolinggo \\ nurulhidayah804@gmail.com
}

\begin{abstract}
This study aims to obtain an overview of the utilization of the historical temple site of Jabung to improve the critical thinking of social science students at the Islamic Institute of Islamic Sciences Zainul Hasan Genggong Probolinggo. The research method used is mixed methods, in which the form of this study combines two approaches namely qualitative and quantitative, this study uses data collection techniques of observation, interviews and tests. The results of data analysis from this study indicate that $\mathrm{T}$ count is -9.439 and $\mathrm{T}$ table is 1.742 which means that $\mathrm{T}$ count is greater than $\mathrm{T}$ table $(-9.439>1.742)$ which means that the utilization of the temple history site as a source of learning can improve the critical thinking of IPS students, the results of this study can also be seen from the results of the tests between pretest and posttest, the test results showed that the average score of pretest was $72.00 \%$, while the average score in the post test was $87.05 \%$. The results of the pretest towards posttets increased by $15.05 \%$. Based on the results of the analysis of the data, it can be concluded that in this study the utilization of the historical sites of Candi Jabung as an effective learning resource can improve the critical thinking of social science students.
\end{abstract}

\section{Keywords: Historical Site, Jabung Temple, Learning Resources, Critical Thinking}

\begin{abstract}
ABSTRAK
Penelitian ini bertujuan untuk memperoleh gambaran tentang pemanfaatan situs sejarah candi Jabung untuk meningkatkan berpikir kritis mahasiswa IPS di Institut ilmu keislaman Zainul Hasan Genggong Probolinggo. Metode penelitian yang digunakan adalah metode campuran, di mana dalam bentuk penelitian ini menggabungkan dua pendekatan yaitu kualitatif dan kuantitatif, penelitian ini menggunakan teknik pengumpulan data observasi, wawancara dan tes. Hasil analisis data dari penelitian ini menunjukkan bahwa $T$ hitung -9,439 dan Ttabel 1,742 yang berarti bahwa $\mathrm{T}$ hitung lebih besar dari Ttabel $(-9,439>1,742)$ yang berarti bahwa pemanfaatan situs sejarah candi sebagai sumber pembelajaran dapat meningkatkan berpikir kritis mahasiswa IPS, hasil penelitian ini juga dapat dilihat dari hasil tes antara pretest dan posttest, hasil tes menunjukkan bahwa skor rata-rata pretest adalah $72,00 \%$, sedangkan skor rata-rata dalam post test adalah $87,05 \%$. Hasil pretest menuju posttets meningkat sebesar $15,05 \%$. Berdasarkan hasil analisis data, dapat disimpulkan bahwa dalam penelitian ini
\end{abstract}


pemanfaatan situs bersejarah Candi Jabung sebagai sumber belajar efektif dapat meningkatkan berpikir kritis mahasiswa IPS.

Kata kunci: Situs Sejarah, Candi Jabung, Sumber Belajar, Berpikir Kritis

\section{PENDAHULUAN}

Proses pembelajaran di Indonesia pada era saat ini memiliki posisi yang sangat strategis dan kompleks, seluruh kegiatan proses pembelajaran bermuara kepada pendidikan. Pendidikan memiliki peran penting dalam pembelajaran, yang mana dalam pembelajaran dibutuhkan peran seorang pendidik agar tercapai tujuan yang diinginkan. Sedangkan untuk mencapai pendidikan di perguruan tinggi dibutuhkan peran dosen sebagai pengajar yang mana dituntut tidak hanya sekedar menyampaikan materi atau pengetahuan kepada mahasiswa namun juga harus menumbuhkan keterampilan mahasiswa. Tiap pengetahuan yang diajarkan oleh dosen dalam pembelajaran di kelas harus sampai membuat mahasiswa memiliki keterampilan berpikir kritis.

Pada era saat ini tujuan pendidikan di Indoensia tidak hanya terpaku pada hasil akhir mahasiswa tetapi terletak pada proses pembelajaran yang terjadi di dalam kelas tersebut dapat meningkatkan dan menumbuhkan segala potensi dan keterampilan yang dimiliki mahasiswa khususnya kemampuan berpikir kritis. Sehingga dengan adanya kemampuan berpikir tingkat tinggi akan membuat mahasiswa mempunyai bekal dalam menghadapi masa depan yang akan datang di dalam kehidupannya.

Kemampuan atau keterampilan berpikir kritis pada era saat ini sangat penting dikembangakan bagi mahasiswa dalam kehidupannya karena merupakan suatu esensi dari dimensi pembelajaran yang berkaitan dengan kehidupan masa depan mahasiswa itu sendiri. Sedangkan realita yang ada di dunia pendidikan di Indonesia dalam proses pembelajaran di perguruan tinggi pada saat ini masih belum cukup mampu meningkatkan kemampuan berpikir kritis mahasiswa secara baik dan menyeluruh. Dikarenakan proses pembelajaran pada saat ini masih terpaku pada tujuan hasil akhir yaitu hanya mengetahui dan memahami pengetahuan yang diperolehnya.

Realita Proses pembelajaran yang ada di perguruan tinggi pada saat ini baik di Negeri maupun Swasta sebagian besar masih terpaku dengan kegiatan belajar berupa menambah pengetahuan atau menstranfer pengetahuan kepada mahasiswa di dalam kelas. Proses pembelajaran masih pada tataran mentrasfer, yaitu menyampaikan pengetahuan dari dosen kepada mahasiswa. Sedangkan bagi mahasiswa yang pasif dan tidak aktif di kelas hanya akan menerima apa saja pengetahuan yang disampaikan oleh dosen tanpa mempunyai kesempatan 
untuk membangun dan mencari sendiri pengetahuan yang dibutuhkannya. Sehingga membuat mahasiswa itu tidak dapat menumbuhkan potensai dan keterampilan yang dimilikinya.

Sedangkan dalam proses pembelajaran mahasiswa diharuskan aktif di dalam pembelajaran di kelas dan menjadi pusat dalam kegiatan belajar mengajar. Sedangkan tugas dosen hanya sebagai fasilitator atau memfasilitasi dalam proses pembelajaran mahasiswa dengan cara dalam pembelajaran di kelas menggunakan cara-cara yang menarik, untuk menumbuhkan minat belajar mahasiswa ${ }^{1}$. Mahasiswa IPS dalam proses pembelajaran harus aktif di kelas dalam mencari pengetahuannya sendiri di dalam pembelajarannya secara utuh agar dapat meningkatkan potensi yang dimilikinya.

Sedangkan permasalahannya bagi mahasiswa IPS dalam pembelajarannya masih belum mampu menumbuhkan kemampuan berpikir kritis. Karena mahasiswa menganggap pembelajaran sangat membosankan. Banyak penyebab yang melatar belakangi adanya permasalahan tersebut, salah satunya menurut penelitian terdahulu yang dilakukan oleh Soemantri yang mana pembelajaran dikatakan sangat menjemukan karena penyajiannya bersifat monoton sehingga mahasiswa kurang antusias dalam pembelajaran sehingga berakibat pada proses belajar mengajar .

Mahasiswa sampai saat ini hanya menjadi pihak yang pasif menerima apa yang disampaikan oleh dosen, sedangkan dosen menjadi pihak yang aktif. Adanya permasalahan tersebut mengakibatkan potensi dan keterampilan yang ada pada diri mahasiswa tidak berkembang dengan baik, sehingga kemampuan berpikir kritis tidak meningkat. Sementara itu pendidikan di INZAH Genggong khususnya pada prodi IPS masih mempunyai permasalahan yaitu kurang meningkatkannya high other thingking (berpikir tingkat tinggi di dalam pembelajarannya.

Kemampuan mahasiswa IPS di INZAH masih di bawah rata-rata, kendala tersebut dikarenakan dominannya peran dosen dalam pembelajaran, mahasiswa hanya dianggap sebagai tempat trasfer ilmu oleh dosen. Selain itu di dalam pembelajaran sumber belajar hanya menggunakan buku dan power point yang telah disiapkan dosen dalam pembelajaran, sedangkan mahasiswa kebanyakan tidak memiliki buku pegangan serta mahasiswa kurang aktif dalam mencari pengetahuannya sendiri.

Adanya kendala tersebut membuat mahasiswa menjadi pasif dalam pembelajaran, jika hanya dosen yang memberikan pengetahuan, sedangkan mahasiswa hanya mendengarkan penjelasan, tanpa mencari pengetahuannya sendiri, akan sulit untuk menumbuhkan kemampuan berpikir kritis. Keadaan di atas menunjukkan bahwa dosen harus membantu mahasiswa untuk membangun pengetahuannya, diperlukan sumber belajar yang efektif untuk dapat

\footnotetext{
${ }^{1}$ Baharuddin., Wahyuni Nur Esa, Teori belajar \& pembelajara, (Yogyakarta: Ar Ruzz Media Group, 2009), hlm 116
} 
menumbuhkan minat mahasiswa dalam pembelajaran sehingga dapat meningkatkan kemampuan berpikir kritis.

Salah satu sumber belajar yang efektif dalam pembelajaran mahasiswa IPS yaitu sumber belajar yang dapat menarik minat mahasiswa dalam pembelajarannya. Sumber belajar yang menarik pada era ini adalah dengan menyajikan pembelajaran di alam bebas, yaitu yang berbasis lingkungan di sekitar kehidupan mahasiswa, yang mana mahasiswa dihadapkan langsung dengan lingkungan yang ada disekitarnya. Pembelajaran di luar kelas saat ini sangat banyak digunakan para pendidik, karena dengan apa yang disajikan di luar kelas akan membuat pola pikir mahasiswa tertarik untuk mengamatinya, khususnya bagi mahasiswa IPS yang berbasic sosial.

Alasan di atas adalah dasar peneliti melakukan penelitian ini, dengan memanfaatkan situs sejarah candi jabung yang ada di sekitar kehidupan mahasiswa sebagai sumber belajar, untuk membuat mahasiswa bersemangat dalam pembelajaran serta agar mahasiswa aktif dalam mengembangkan pola berpikirnya. Situs sejarah di Indonesia begitu banyak, berbagai peninggalan nenek moyang yang berada di wilayah Indonesia, salah satunya adalah situs sejarah candi jabung yang ada di daerah Jabung Kota Probolinggo.

Maka dari itu dengan adanya penelitian ini diharapkan dengan situs sejarah candi jabung tidak hanya dapat meningkatkan berpikir kritis mahasiswa IPS tetapi juga mengenalkan peninggalan-peninggalan sejarah yang perlu sebagai generasi muda untuk melestarikan situs sejarah tersebut. Sedangkan Urgensi dalam penelitian penilitian ini adalah untuk mengetahui efektivitas sumber belajar situs sejarah candi jabung untuk meningkatkan berpikir kritis mahasiswa IPS.

\section{METODE PENELITIAN}

Metode penelitian yang digunakan pada penelitian ini yaitu mixed methods, yang mana penelitian ini merupakan penggabungan dari dua bentuk pendekatan yaitu kualitatif dan kuantitatif. Menurut Creswell penelitian campuran merupakan penelitian yang mengkombinasikan antara penelitian kualitatif dengan penelitian kuantitatif. ${ }^{2}$ Menurut Sugiyono metode penelitian kombinasi (mixed methods) adalah suatu metode penelitian yang mengkombinasikan atau menggabungkan antara metode kuantitatif dengan metode kualitatif untuk digunakan secara bersama-sama dalam suatu kegiatan penelitian, sehingga diperoleh data yang lebih komprehensif, valid, reliable dan obyektif. ${ }^{3}$

\footnotetext{
${ }^{2}$ Creswell. John. W, Research Design, Pendekatan Kualitatif, Kuantitatif, dan Mixed Method, Jakarta: Pustaka Pelajar, 2011, Hal 11.

${ }^{3}$ Sugiyono, Metode Penelitian Kombinasi (Mixed Methods), Bandung: Alfabeta, 2011. Hal 404.
} 
Metode Mixed Method Research memberikan panduan pada saat mengumpulkan dan menganalisis data penelitian, dan menggabungkan antara pendekatan kualitatif dan kuantitatif yang dilakukan dalam satu serangkaian penelitian. Peneliti memilih menggunakan metode penelitian Mixed Method Research ini dengan beberapa pertimbangan karena ingin menganalisis sejauh mana kemampuan berpikir kritis mahasiswa IPS dalam memanfaatkan situs sejarah candi jabung sebagai sumber belajar.

Teknik pengumpulan data dalam penelitian ini menggunakan teknik observasi, wawancara dan tes melalui uji pretest dan posttest. Subyek yang digunakan dalam penelitian ini adalah mahasiswa IPS di Institut Ilmu Keislaman Zainul Hasan (INZAH) Genggong Probolinggo. Sedangkan hasil berpikir kritis mahasiswa IPS terhadap sumber belajar berbasis situs sejarah candi jabung dalam penelitian ini akan dianalisa menggunakan ketuntasan individual, ketuntasan klasikal, dan uji T melalui SPSS.

\section{HASIL DAN PEMBAHASAN}

Berdasarkan hasil penelitian yang telah peneliti lakukan kepada mahasiswa IPS di Institut ilmu keislaman zainul hasan genggong, yang mana dalam penelitian ini untuk mendapatkan hasil yang sesuai, peneliti telah melakukan uji pretest dan posttest pada mahasiswa IPS untuk mengetahui apakah ada peningkatan berpikir kritis setelah memanfaatkan situs sejarah candi jabung sebagai sumber belajar. Hasil nilai pretest dan posttest mahasiswa IPS yang dalam penelitian ini dapat dilihat pada tabel 1 di bawah ini.

Tabel 1 Pre Test dan Post Test

\begin{tabular}{clccccc}
\hline No & \multicolumn{1}{c}{ Nama } & $\begin{array}{c}\text { Pre } \\
\text { Test }\end{array}$ & $\begin{array}{c}\text { Kriteria } \\
\end{array}$ & $\begin{array}{c}\text { Post } \\
\text { Test }\end{array}$ & Kriteria & Keterangan \\
\hline 1 & Ahmad Muchlisin & 75 & $\mathrm{~T}$ & 83 & $\mathrm{~T}$ & Meningkat \\
2 & Badrus Sholeh & 75 & $\mathrm{~T}$ & 86 & $\mathrm{~T}$ & Meningkat \\
3 & Desi Anisatul Hasanah & 80 & $\mathrm{~T}$ & 84 & $\mathrm{~T}$ & Meningkat \\
4 & Diyaul Badri & 75 & $\mathrm{~T}$ & 85 & $\mathrm{~T}$ & Meningkat \\
5 & Faizah Melani & 80 & $\mathrm{~T}$ & 83 & $\mathrm{~T}$ & Meningkat \\
6 & Fatmawati & 96 & $\mathrm{~T}$ & 97 & $\mathrm{~T}$ & Meningkat \\
7 & Febri Hasan Afini Maulaya & 75 & $\mathrm{~T}$ & 92 & $\mathrm{~T}$ & Meningkat \\
8 & Firnando Hidayat & 75 & $\mathrm{~T}$ & 88 & $\mathrm{~T}$ & Meningkat \\
9 & Ghoniyun Inayaturrohman & 75 & $\mathrm{~T}$ & 86 & $\mathrm{~T}$ & Meningkat \\
10 & Hasbullahur Mukarromah & 80 & $\mathrm{~T}$ & 92 & $\mathrm{~T}$ & Meningkat \\
11 & Jamaluddin & 75 & $\mathrm{~T}$ & 91 & $\mathrm{~T}$ & Meningkat \\
12 & Khofifatur Rohmah & 75 & $\mathrm{~T}$ & 89 & $\mathrm{~T}$ & Meningkat \\
13 & Mohamad Fadil & 75 & $\mathrm{~T}$ & 86 & $\mathrm{~T}$ & Meningkat \\
14 & Mohammad Fadil MB & 75 & $\mathrm{~T}$ & 83 & $\mathrm{~T}$ & Meningkat \\
\hline
\end{tabular}




\begin{tabular}{llccccc}
\hline 15 & Mohammad Ilham & 52 & $\mathrm{TT}$ & 75 & $\mathrm{~T}$ & Meningkat \\
16 & Muhammad Toubet & 75 & $\mathrm{~T}$ & 86 & $\mathrm{~T}$ & Meningkat \\
17 & Sundus Nuril Firdausi & 77 & $\mathrm{~T}$ & 87 & $\mathrm{~T}$ & Meningkat \\
18 & Tuti'il Khoiroh & 77 & $\mathrm{~T}$ & 89 & $\mathrm{~T}$ & Meningkat \\
19 & Yusrina Zaharini & 77 & $\mathrm{~T}$ & 92 & $\mathrm{~T}$ & Meningkat \\
& Jumlah & 1444 & & 1654 & & Meningkat \\
& Skor Rata-Rata & 72,00 & & 87,05 & & Meningkat \\
& & & & & \\
\hline
\end{tabular}

Berdasarkan tabel 1 hasil kegiatan uji pretest dan posttest di atas dapat menunjukkan bahwa kondisi awal tingkat kemampuan berpikir kritis mahasiswa IPS, pada tahap hasil uji pretest dengan hasil kategori sedang masih cukup tinggi. Sebanyak 14 mahasiswa masih memiliki tingkat kemampuan berpikir kritis yang sedang (cukup baik), yaitu rata-rata nilai pre test 75 . Melalui tabel 1 di atas juga dapat diketahui bahwa sebanyak 4 mahasiswa masuk dalam kategori baik untuk aspek kemampuan berpikir kritis, dan 1 mahasiswa memiliki berpikir kritis yang rendah.

Tabel 1 di atas juga menujukkan bahwa rata-rata pada uji pre test sebesar $72.00 \%$ sedangkan pada uji post test meningkat sebesar $87.05 \%$, yang artinya terjadi peningkatan sebesar $15,05 \%$ dari nilai pretest menunju post test. Hasil tersebut menunjukkan bahwa kemampuan berpikir kritis mahasiswa IPS mengalami peningkatan pada sebelum dan sesudah memanfaatkan situs sejarah candi jabung sebagai sumber belajar. Peningkatan hasil berpikir kritis tersebut dapat dilihat pada gambar grafik di bawah ini.

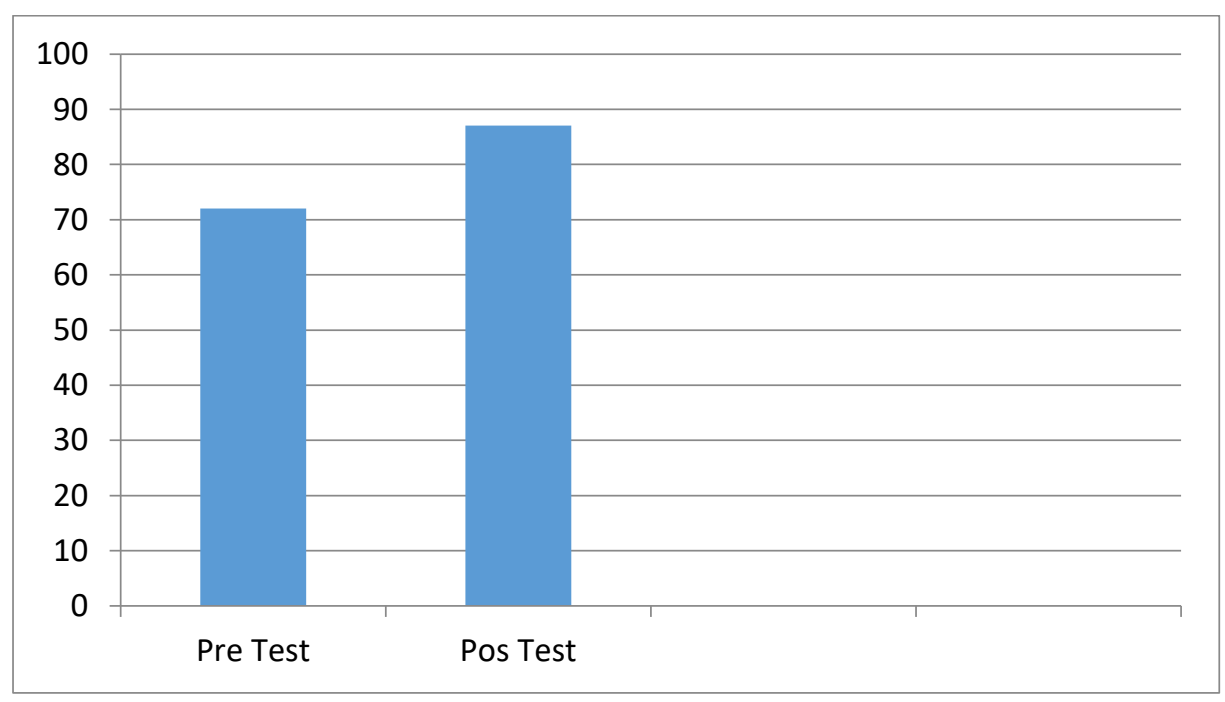

Gambar 1 Grafik Peningkatan Hasil PreTest dan PostTest

Pada gambar $1 \mathrm{di}$ atas menunjukkan bahwa hasil perbandingan antara pre test dan posttest tersebut menunjukkan bahwa terdapat peningkatan antara 
sebelum dan sesudah memanfaatkan situs sejarah candi jabung sebagai sumber belajar IPS. Hasil tersebut menunjukkan terjadi peningkatan sebesar 15,05\% pada uji pretest menuju posttest. Sedangkan gambar Prosentase pada uji pre test dan post test dapat dilihat di bawah ini, sebagai berikut.

\section{Prosentase Hasil Berpikir Kritis}
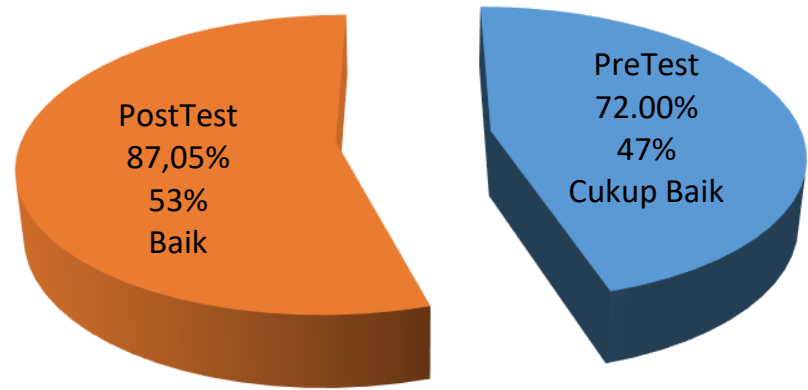

Gambar 2 Grafik Prosentase Hasil PreTest dan PostTest Berpikir Kritis

Pada gambar 2 di atas menunjukkan bahwa prosentase pada hasil pretest dan posttest menunjukkan terjadi peningkatan. Pada saat pretest sebesar 72,00\% dengan kategori rendah, sedangkan pada pretest sebesar 87,50.\% dengan kategori baik. Adanya gambar di atas menunjukkan hasil peningkatan yang baik. Selanjutnya untuk mengetahui hasil tingkat korelasi antara hasil pretest dan posttest selain dari segi individual dan klasikal peneliti juga melakukan uji $\mathrm{T}$, Hasil uji T dalam penelitian ini dapat dilihat pada Tabel 2 di bawah ini.

Tabel 2 Uji T

\begin{tabular}{rrrrrc}
\hline & & Mean & N & Std. Deviation & \multicolumn{1}{c}{$\begin{array}{c}\text { Std. Error } \\
\text { Mean }\end{array}$} \\
Pair 1 & Pretest & 76,00 & 19 & 7,594 & 1,742 \\
& Postest & 87,0526 & 19 & 4,76648 & 1,09350 \\
\hline
\end{tabular}

Tabel 3. Hasil Paired Samples Test 


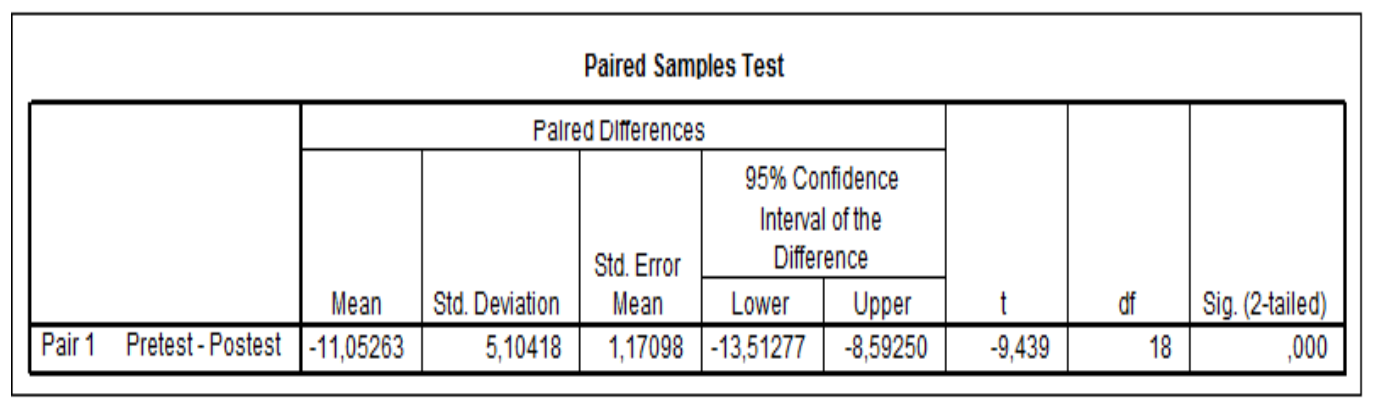

Tabel 2 dan 3 di atas menunjukkan bahwa hasil uji T dengan melalui paired sample T-test menggunakan SPSS 15,0 untuk mengetahui perbedaan antara kemampuan berpikir kritis pada pre test dan post test. Hasil tersebut dapat disimpulkan bahwa nilai T-hitung sebesar -9.439, sedangkan T-tabel pada penelitian ini yaitu df 18 dengan taraf significant 5\% maka diperoleh T-tabel sebesar 1.742 .

Dengan demikian, dapat disimpulkan bahwa T-hitung $>$ T-tabel $(-9,439>1.742)$, sehingga menunjukkan $\mathrm{H} 1$ diterima $\mathrm{H}_{0}$ ditolak artinya ada perbedaan antara sebelum dan sesudah dilaksanakan pembelajaran IPS memanfaatkan situs sejarah candi jabung sebagai sumber belajar. Selanjutnya hasil data pada kolom Sig (2-tailed) juga menunjukkan bahwa nilai pvalue $<$ level of significant $5 \% \quad(0,000<0,05)$, yang artinya diterima $\mathrm{Ha}$ menunjukkan bahwa adanya hubungan yang significant terhadap peningkatan kemampuan berpikir kritis siswa antara uji pretest dan posttest.

Adanya hasil peningkatan berpikir kritis mahasiswa di atas menunjukkan bahwa pemanfaatan situs sejarah candi jabung sangat efektif digunakan dalam pembelajaran IPS. Hal tersebut sesuai dengan teori kontruktivisme, yaitu bahwa pentingnya mahasiswa membangun sendiri pengetahuannya dan terlibat aktif dalam pembelajaran. Pada pembelajaran kontruktivisme lebih memusatkan proses berpikir tingkat tinggi mahasiswa dari pada sekedar pada hasilnya tetapi mengutamakan peran mahasiswa dalam berinisiatif sendiri untuk terlibat dalam pembelajaran. ${ }^{4}$

Pengenalan situs-situs sejarah sangat dibutuhkan mahasiswa IPS dalam pembelajaran, selain untuk menarik minat belajar mahasiswa juga untuk efektif dapat meningkatkan kemampuan berpikir kritis, Selain itu juga dengan mengenalkan situs sejarah sebagai sumber belajar dapat menumbuhkan minat mahasiswa dalam mengetahui peninggalan-peninggalan sejarah, karena tugas mahasiswa IPS sebagai penerus bangsa dalam melestarikan peningalan nenek moyang. ${ }^{5}$

\footnotetext{
${ }^{4}$ Fisher, Alec,. Berpikir kritis: Sebuah pengantar, Jakarta: Erlangga, 2009. Hlm 75.

${ }^{5}$ Baharuddin., Wahyuni Nur Esa, Teori belajar \& pembelajara, (Yogyakarta: Ar Ruzz Media Group, 2009), hlm 124.
} 
Seperti yang dikatakan Vygotsky dalam pendidikan lebih menekankan pada pentingnya lingkungan sosial dalam proses belajar mengajar dengan mengintegrasikan atau menghubungkan kemampuan belajar kelompok untuk dapat meningkatkan pengubahan pengetahuan secara konseptual. ${ }^{6}$ Seperti yang dikatakan Vygotsky bahwa dalam pembelajaran melibatkan 2 elemen yang sangat penting salah satunya berkaitan erat dengan lingkungan sosial budaya. ${ }^{7}$

Adanya teori dari Vygotsky di atas menunjukkan bahwa pemanfaatan situs sejarah candi jabung efektif dapat meningkatkan kemampuan mahasiswa dalam berpikir kritis, belajar berdasarkan apa yang ada di lingkungan sekitar mahasiswa akan lebih menarik minat belajar mahasiswa dalam menggali pengetahuan yang sudah ada dengan memasukan pengetahuan baru. ${ }^{8}$

Pengetahuan mahasiswa IPS yang sudah ada akan membuat mahasiswa berpikir kritis untuk mengaitkan dengan apa yang diketahui sebelumnya ke dalam pengetahuan yang baru dengan situs sejarah candi jabung, Seperti yang dikemukakan oleh Vygotsky bahwa perubahan perkembangan kognitif peserta didik terjadi ketika konsep-konsep yang sebelumnya sudah ada mulai bergeser karena ada sebuah informasi baru yang diterima mahasiswa. ${ }^{9}$

\section{KESIMPULAN}

Berdasarkan hasil penelitian yang telah dipaparkan di atas dapat diambil kesimpulan bahwa pemanfaatan situs sejarah candi jabung sebagai sumber belajar dapat meningkatkan berpikir kritis mahasiswa IPS. Hal ini ditunjukkan oleh perubahan yang signifikan pada tingkat dan antusias mahasiswa dalam mengikuti pembelajaran serta persentase ketercapaian hasil test mahasiswa, yang mana dapat dilihat dari hasil pretest dan posttest yang mengalami peningkatan.

Hasil tes dari pretest dan posttest yang mengalami peningkatan atau kenaikan, pada uji pretest tahap sebelum diterapkan pemanfaatan sumber belajar situs sejarah candi jabung sebanyak 14 mahasiswa masih kategori cukup baik, 4 mahasiswa berkategori baik, dan 1 mahasiswa berkategori sangat kurang. Sedangkan pada posttest 19 mahasiswa telah tuntas, dengan 18 mahasiswa berkategori baik, dan 1 mahasiswa berkategori sedang/cukup baik.

Dari kedua tahap tersebut sebelum memanfaatkan situs sejarah candi jabung dan sesudah memanfaatkan situs sejarah candi jabung sebagai sumber belajar dalam pembelajaran. Kemampuan siswa rata-rata dari 72,00\% meningkat menjadi $87,05 \%$, terjadi peningkatan sebesar $15,05 \%$ dari pretest menuju posttest, yang artinya berdasarkan hasil tersebut menunjukkan bahwa situs

\footnotetext{
${ }^{6}$ Ibid, hlm 117

${ }^{7}$ Ibid, hlm 124

${ }^{8}$ Munadi, Yudhi, Media pembelajaran (sebuah pendekatan baru), Jakarta: Referensi (GP Press Group), 2013. hlm 25 .

${ }^{9}$ Baharuddin., Wahyuni Nur Esa, Teori belajar \& pembelajara, (Yogyakarta: Ar Ruzz Media Group, 2009), hlm 117.
} 
sejarah candi jabung efektif digunakan untuk meningkatkan kemampuan berpikir kritis siswa.

Saran penulis untuk semua pendidik baik guru maupun dosen hendaknya dalam pembelajaran perlu menyiapkan sumber belajar yang dapat menarik minat belajar peserta didik, diharapkan tidak hanya menggunakan sumber belajar yang monoton yang ada di dalam kelas. Pendidik perlu menerapkan sumber belajar yang melibatkan langsung peserta didik belajar menerima apa yang ada di lingkungan kehidupannya, karena dengan peserta didik dihadapkan pada lingkungan kehidupannya akan membantu minta belajar peserta didik serta menumbuhkan potensi berpikir kritis peserta didik.

\section{DAFTAR PUSTAKA}

Arikunto, Prosedur penelitian: Suatu pendekatan praktik. (edisi revisi), Jakarta: Rineka Cipta, 2010.

Bachman, E, Metode belajar berpikir kritis dan inovatif, Jakarta: Prestasi Pustaka, 2005.

Baharuddin., Wahyuni Nur Esa. (2009), Teori belajar \& pembelajaran, Yogyakarta: Ar Ruzz Media Group, 2009.

Creswell. John. W, Research Design, Pendekatan Kualitatif, Kuantitatif, dan Mixed Method, Jakarta: Pustaka Pelajar, 2011.

Eko Muhammad Arif Budiono, dkk, Nilai Edukasi Candi Jabung Kecamatan Paiton Kabupaten Probolinggo dalam Pembelajaran Sejarah, Sindang, Jurnal Pendidikan Sejarah dan Kajian Sejarah, Vol 1 No 2 Desember 2019.

Ennis, R. H, Critical Thinking Test, USA Bright Minds, 2005.

Ennis, Robert $\mathrm{H}$, The nature of critical thinking:an outline of critical thinking dispositions and abilities, 2011, Diambil 15 Januari 2016 dari http://faculty.education.illinois.edu/rhennis/documents/TheNatureofCriticalThin king_51711_000.pdf.

Fisher, Alec, Berpikir kritis: Sebuah pengantar, Jakarta: Erlangga, 2009.

Iskandar, D, Metodologi penelitian pendidikan dan sosial (kuantitatif dan kualitatif), Jakarta: Gaung Persada Press, 2009. 
Jurnal Tinta, Vol. 1 No. 2, September 2019, Hal. 44-54

Mulyana, Deddy, Metodologi penelitian kualitatif: Paradigma baru ilmu komunikasi dan ilmu sosial lainnya, Bandung: PT. Remaja Rosdakarya, 2008.

Mustaji, Pengembangan kemampuan berpikir kritis dan kreatif dalam pembelajaran di sekolah, Journal Pendidikan sekolah dasar, vol 5 no 5, 2009.

Naji, Sholeh, Candi Jabung Di Desa Jabung Candi, Paiton, Probolinggo, Jawa Timur (Sejarah, Fungsi, Dan Potensinya Sebagai Sumber Belajar Sejarah Di Sma), Widya Winayata: Jurnal Pendidikan, Vol 8, No 2, 2017.

Siti Nurul Hidayah, Pengembangan Bahan Ajar IPS Berbasis Keragaman Budaya Batik Jenogoroan untuk Meningkatkan Berpikir Kritis Siswa, Jurnal Ed-Humanistics. Volume 04 Nomor 01 Tahun 2019.

Pannen, I aulina, Kontrukvisme dalam pembelajaran direktorat jendral pendidikan tinggi, 2001.

Sugiyono, Metode Penelitian Kombinasi (Mixed Methods), Bandung: Alfabeta, 2011.

Sugiyono, Pendekatan kuantitatif, kualitatif dan $r \& d$, Bandung: Alfabeta, 2011.

Tantri Raras Ayuningtyas,dkk, Pemanfaatan Situs Peninggalan Sejarah Di Kabupaten Bondowoso Sebagai Pengembangan Sumber Belajar Di Sekolah Lanjutan Atas Di Kabupaten Bondowoso, Historia: Jurnal program studi pendidikan Sejarah, Vol 6 No 12018.

Wahidmurni, M, Cara mudah menulis proposal dan laporan penelitian lapangan, Malang: Universitas Negeri Malang, 2008 